\title{
The Effect of Transformational Leadership and Organizational Culture on Behavior Employee Innovative with Knowledge Management as Intervening Variables (Case Study of Financial Education and Training Agency)
}

\author{
Rio Suareski ${ }^{1}$, Lenny C Nawangsari ${ }^{2}$ \\ \{rio.suareski@kemenkeu.go.id ${ }^{1}$, Lenny.christina@mercubuana.ac.id² \\ Universitas Mercu Buana, Jakarta, Indonesia ${ }^{12}$
}

\begin{abstract}
This study aims to determine the transformational leadership effect and organizational culture on innovative behavior of employees in Financial Education and Training Agency. This research is a quantitative object research of employees in the Financial Education and Training Agency environment in October 2019 to April 2020. The variables used are independent variables namely transformational leadership and organizational culture, the dependent variable is innovative behavior, and the intervening variable is knowledge management. The study population numbered 928 employees at BPPK with proportionate stratified random sampling techniques. The research data source is primary data through questionnaires to employees of the Financial Education and Training Agency. Data collection techniques using instruments questionnaire. The study are as follows: (1) Transformational leadership has a positive and significant effect on Knowledge Management, (2) Organizational Culture has a positive and significant effect on Knowledge Management, (3) Transformational Leadership has a positive and significant effect on Employee Innovative Behavior, (4) Organizational Culture has a positive and significant effect on Employee Innovative Behavior, (5) Knowledge Management has positive and significant effect on Employee Innovative Behavior, (6) Transformational Leadership has positive and significant effect on Employee Innovative Behavior through Knowledge Management, (7) Organizational Culture has positive and significant effect on Employee Innovative Behavior through Knowledge Management, (8) Transformational Leadership and Organizational Culture has a positive and significant effect on Knowledge Management, and (9) Transformational Leadership, Organizational Culture has a positive and significant effect on Employee Innovative Behavior through Knowledge Management.
\end{abstract}

Keywords: transformational leadership, organizational culture, innovative behavior, Financial Education and Training Agency

\section{Introduction}

Now on, in digital era, the ability of an organization to produce competitive advantage depends in part on the organization's ability to innovate. Innovation is an important element as an effective tool for business continuity and resilience [1]. Its application to organizations 
can help in developing opportunities that exist, starting from identifying problems in performance, processes and systems as the aim of providing alternative solutions for solving problems faced by the organization. Each organization has a different way in an effort to improve employee innovative behavior [2]. To come up with new ideas and multitasking processes employees must have the organizational support leaders in providing opportunities to produce quality products [3]. The leader is the originator of idea goals, planning, organizing, moving and controlling all organizational resources so that goals can be achieved effectively and efficiently [4]. One form of leadership that is able to streamline learning organizations is transformational leadership.

Leadership transformation is a comprehensive and integrated leadership ability needed for individuals, groups, and organizations to produce transformations that are marked by changes at each stage of activity [5]. Leaders who have a transformational leadership style increase employee awareness and support higher quality work and innovation that is more than expected [6]. As research conducted by Choi et al., [7] which concluded that transformational leadership has a great influence on the innovative behavior exhibited by employees so as to make it easy for organizations to build innovation. However, there are studies that produce different test results, according to [8], it shows that transformational leadership does not have a significant effect on innovative behavior on Tour and Travel company employees in West Sumatra. The gap between the study results is the basis for the authors to conduct research that will be conducted next.

In addition to transformational leadership, organizational culture is also predicted to be able to influence innovative behavior exhibited by employees in the organization [9]. Organizational culture is an organizational environment where employees perform work that affects employees both positively and negatively to achieve the expected goals [9]. Even organizational culture gives a strong influence on employee behavior at work and has an important role in every process of organizational improvement [19].

The problems discussed in this are the implementation of innovative behavior and the use of Knowledge Management that is still low in government organizations by object of study regarding the innovative implementation behavior and the use of Knowledge Management is the Financial Education and Training Agency (BPPK). This is interesting to study because BPPK is a training organization that is institutionally, very aware of the importance of innovative behavior and Knowledge Management to improve the competency and competitiveness of the organization and its employees, especially the duties and functions of BPPK, one of which is developing HR competencies at the Ministry of Finance.

The author also conducted a pre-survey to obtain input from actual employees what factors most influence innovative behavior in supporting the environment in the organization of the object of research. The author provides several alternative variables that might affect innovative behavior, including: (a) Transformational Leadership, (b) Organizational Culture, (c) Knowledge Management, (c) Work Engagement, (e) Competitive Pressure. From the five variables, $3 \mathrm{x}$ variables were obtained which were considered to be fulfilling respondents namely Transformational Leadership, Organizational Culture and Knowledge Management.

Based on 46 respondents BPPK employees stated that which influencing innovative behavior is Organizational Culture by $26 \%$, Transformational Leadership 25\%, Knowledge Management 22\%, Work Management 14\% and Competitive Pressure 13\%. After obtaining the 3 factors that most influence the innovative behavior of pre-survey employee results, the authors conducted a pre-survey follow up to find out how much influence the variables that support these invasive behavioral factors. From the results of the pre-survey follow up, it can be seen that there is still not a maximum of factors that affect employees behaving 
innovatively. For the Transformational Leadership factor of the 5 statements obtained an average of respondents stated agree is $68.9 \%$, meaning there is still a gap of $31.1 \%$ which needs to be improved in terms of Transformational Leadership that supports innovative employee behavior. Organizational Culture Factors of the 5 (statements) the authors tested obtained an average of $65.2 \%$ who agreed, this result also illustrates the lack of optimal organizational culture that supports employee innovative behavior. As for the factor Knowledge Management of 5 (five) statements obtained an average of $64.3 \%$ who agreed, this is the lowest value of the 3 factors influencing innovative behavior tested by the author.

Based on the description that has been described above, the authors are interested in conducting research entitled "The Effect of Transformational Leadership and Organizational Culture on Employee Innovative Behavior with Knowledge Management as an Intervening Variable case study in the Financial Education and Training Agency". This research is expected to provide benefits in growing and improving employee innovative behavior. The following is a literature review of the variables studied, among others:

\subsection{Transformational Leadership Transformational}

Leadership is a unique leadership, where leaders have the ability to understand the employee's main talents and influence employee's moral values and ethics in such a way that they tend to perform better than expected or provide services prime. Transformational leadership broadly focuses on consideration, intellectual stimulation, and inspirational motivation from individuals. Moreover, transformational leaders are considered to be more trustworthy, realistic, and practical, which can help them to complete their tasks and also have the potential to stimulate innovative work behavior [15].

\subsection{Organizational Culture Organizational}

Culture is the control element of the organization which acts as a driving force and development. This strength gives employees a sense of identity and provides guidelines for understanding within the organization, which determines their existence by giving them values, norms and guidance.

\subsection{Knowledge Management KM(KM)}

Is a function of planning, coordinating and controlling the flow of knowledge produced by related organizations? with administrative, technical or process activities within the organization. KM can also be interpreted as the process of creating, capturing, and using knowledge to improve organizational performance.

\subsection{Employee Innovative Behavior Innovative}

Behavior is defined as the overall individual action that leads to the emergence, recognition, and application of something new and beneficial at all levels of the organization. [21] defines innovative behavior in the workplace Innovative Work Behavior (IWB) as individual behavior that aims to reach the stage of recognition or attempt to introduce (in work, groups or organizations) ideas, processes, products or procedures new and useful.

From the theory and empirical studies study the researcher proposes the following hypothesis:

H1: Transformational Leadership has a positive and significant effect on Knowledge Management.

$\mathrm{H} 2$ : Organizational culture has a positive and significant effect on Knowledge Management. 
H3: Transformational leadership has positive and significant effect on innovative behavior.

H4: Organizational Culture has a positive and significant effect on innovative behavior.

H5: Knowledge Management has a positive and significant effect on innovative behavior.

H6: Transformational leadership indirectly through Knowledge Management has a positive and significant effect on innovative behavior.

H7: Organizational culture indirectly through Knowledge Management has a positive and significant effect on innovative behavior.

H8: Transformational leadership and organizational culture have a positive and significant effect on Knowledge Management.

H9: Transformational leadership, organizational culture and Knowledge Management have positive and significant influence on innovative behavior.

\section{Research Method}

This research is a quantitative research. Research this is accompanied by activities which include collecting data in order to test hypothesis to answer questions concerning phenomena and their relationships with the subject of a study. This research was conducted in the Financial Education and Training Agency, Ministry of Finance in October 2019 until April 2020 with the object of employees in the Financial Education and Training Agency environment. The variables in this study are independent variables namely transformational leadership and organizational culture, the dependent variable is innovative behavior, and intervening variable is knowledge management. The population in this study were employees in the Financial Education and Training Board, totaling 928 employees at the Head Office. The sampling technique used in this study is proportionate stratified random sampling.

The source of the data in this study is primary data obtained by distributing questionnaires to parties directly related to the research, namely employees of the Financial Education and Training Agency. While the data collection techniques used in this study used a questionnaire instrument. The data analysis method was carried out several stages. The first is the validity test using the technique Product Moment Correlation as follows:

$$
\mathrm{r}_{\mathrm{xy}}=\frac{N \sum X Y-\left(\sum X\right)\left(\sum Y\right)}{\sqrt{\left(N X^{2}-\left(\sum X^{2}\right)\left(N Y^{2}-\left(\sum Y^{2}\right)\right.\right.}}
$$

Note:

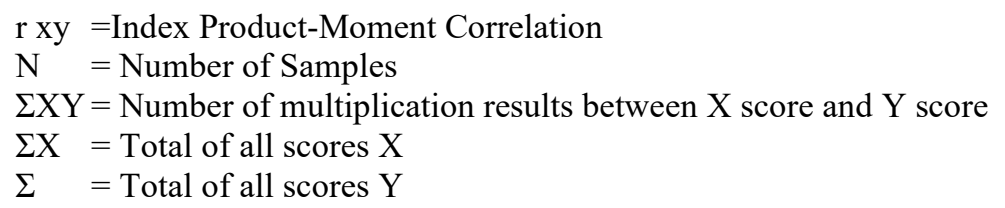

Significance test is done by comparing the value of $r$ count with $r$ table for degree of freedom $(\mathrm{df})=\mathrm{n}-2$, in this case $\mathrm{n}$ is the number of samples and alpha $=0.05$. If $\mathrm{r}$ count is greater than $r$ table and a positive value, then the item or question or indicator is declared valid [10]. Next is the reliability test to show the extent to which a measuring instrument (questionnaire) can provide consistent results if measurements are made again on the same subject at different times. The third step is Partial Least Square (PLS). PLS is a predictive technique that can solve many independent variables, even if there is multicollinearity among 
these variables [11]. PLS method is a powerful analysis method because it does not assume the data must be with a certain scale measurement, the number of samples is small [10]. PLS aims to help researchers to get the latent variables value (hypothesis testing) for predictive purposes.

\section{Results and Discussion}

\subsection{Results}

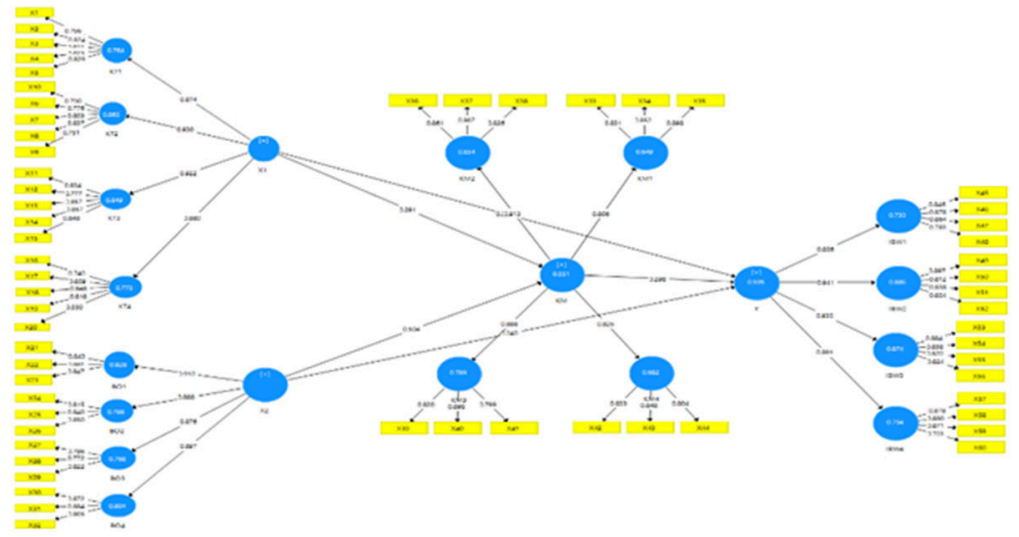

\subsubsection{Outer model testing}

This model defines how each indicator relates to its latent variable, or it can be said that the outer model can specify the relationship between the latent variable and its indicators. Tests conducted on the outer model using the technique Confirmatory Factor Analysis (CFA). The confirmatory factor analysis constructs used to see the validity of each indicator and to test the reliability of the construct. In this study, the validity criteria based on the reflexive indicator model measured by convergent validity and discriminant validity. The indicator is said to meet convergent validity if the value is loading factor above 0.7 but for the initial stage of research the development of a loading value of 0.5 to 0.6 is considered sufficient, and is indicated by the Average Variance Extracted (AVE) value above 0.50. Construct reliability is measured by Composite Reliability and Cronbach's Alpha. The construct is said to be reliable if it has a value Composite Reliability and Cronbach Alpha $>$ $0.70[10]$.

Table 1. AVE (Average Variance Extracted) and Composite Reliability Value of the Research Model

\begin{tabular}{cc|}
\hline Variabel & $\begin{array}{c}\text { AVE } \\
\text { Value }\end{array}$ \\
\hline Kepemimininan Transformasional $\left(\mathrm{X}_{1}\right)$ & 0.523 \\
\hline Budaya Organisasi $\left(\mathrm{X}_{2}\right)$ & 0.562 \\
\hline Knowiedge Monagement $(\mathrm{Z})$ & 0.527 \\
\hline Penlaku Inovatif Pegawain $(\mathrm{Y})$ & 0.586 \\
\hline
\end{tabular}

\begin{tabular}{|c|c|c|c|}
\hline Variabel & $\begin{array}{l}\text { Composile } \\
\text { Reliability }\end{array}$ & $\begin{array}{l}\text { Cronbachs } \\
\text { Alphe }\end{array}$ & Keterengan \\
\hline $\begin{array}{c}\text { Kepemimipinan } \\
\text { Transformasional }\left(\mathrm{X}_{1}\right)\end{array}$ & 0.956 & 0.951 & Reliabel \\
\hline Budrya Organtast (X) & 0939 & 0.928 & Reliabe \\
\hline Khowledpe Managemert (Z) & 0930 & 0.918 & Retiabe \\
\hline Penlaku Inovatif Pegawai (Y) & 0.958 & 0.952 & Reliabel \\
\hline
\end{tabular}

From the data in table 1 it appears the value of AVE of all research variables is greater than 0.5, so the test Discriminant validity has been fulfilled which means this research model is valid. And seen from table 2 it is concluded that the model meets the Composite Reliability and Cronbach's Alpha criteria so that it meets the reliability criteria and is a reliable and reliable measuring tool. 


\subsubsection{Testing the Inner Model}

This model is a specification of relationships between latent variables, also called inner relations. In this test is a test of the type and magnitude of influence of the independent latent variable on the dependent latent variable. This test consists of 2 stages, namely the R Square Determinant Coefficient $\left(\mathrm{R}^{2}\right)$ test that calculate how much the independent latent variable explains the variance of the dependent latent variable and test the hypothesis which is a test of the research model hypothesis.

Table 2. R Square $\left(\mathrm{R}^{2}\right)$ Value of the Research Model

\begin{tabular}{|c|c|c|}
\hline Konstruk & R Square & R Square Adjusted \\
\hline Knowledge Management (Z) & 0.551 & 0.542 \\
\hline Perilaku Inovatif Pegawai (Y) & 0.595 & 0.582 \\
\hline
\end{tabular}

Based on the coefficient test results of determination presented in table 3, the R-square Adjusted value for the variable Knowledge Management 0.542 shows that $54.2 \%$ variable Knowledge Management (Z) can be affected by variables Transformational Leadership (X1), and Cultural Organization (X2), while the remaining $45.8 \%$ is influenced by other variables outside the studied authors. While the relationship between constructs Employee Innovative Behavior variable $(\mathrm{Y})$ is equal to 0.582 , this shows that $58.2 \%$ of Transformational Leadership variables (X1), and Organizational Culture (X2), and Knowledge Management variables $(Z)$, while the remaining $41.8 \%$ is influenced by other variables outside the study. If seen from the criteria, the R-Square values for the variables are in the moderate as strong category.

Table 3. Path Analysis values from the Research Model

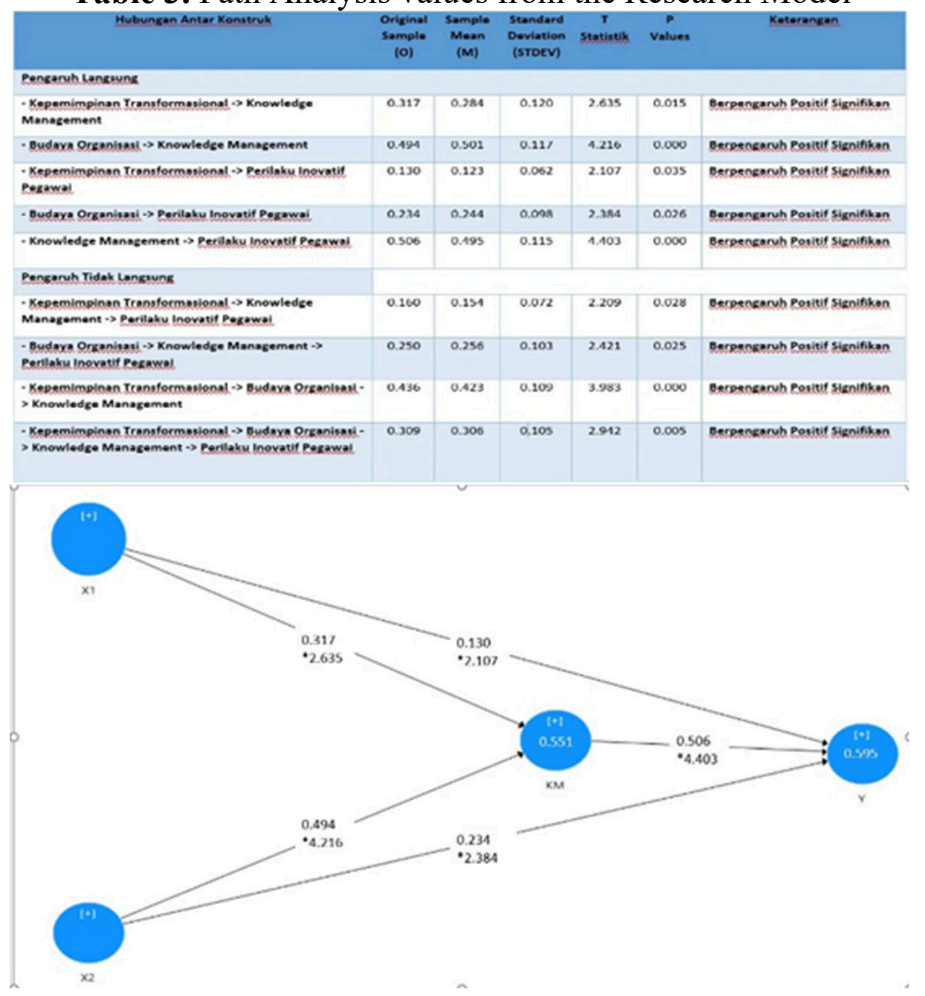


Based on the Path coefficient estimation test results in table 4, shows that the path coefficient value or the magnitude of the relationship / effect of latent constructs, the results obtained that the value of the path coefficient is entirely positive.

\subsubsection{Overall Structural Model Validation with the Goodness of fit index (GoF)}

The Goodness of Fit Index (GoF) test aims to validate the combined performance of the measurement model (outer model) and the structural model (inner model) obtained through the following:

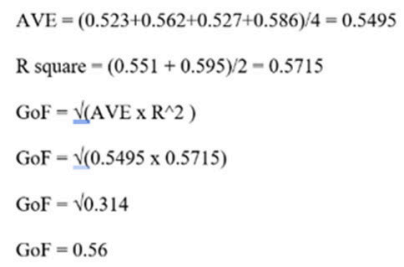

from the calculation of Fit Index ( $\mathrm{GoF}$ ) Goodness calculation results shows the value of 0.56. [10] a small $\mathrm{GoF}$ value $=0.1$, a medium $\mathrm{GoF}=0.25$ and a large $\mathrm{GoF}=0.36$. Based on these results it can be concluded that the combined performance of the measurement model (outer model) and structural model (inner model) as a whole is good because the Goodness of Fit Index $(\mathrm{GoF})$ value is more than 0.36 (large scale $\mathrm{GoF}$ ).

\subsection{Discussion}

\subsubsection{Transformational Leadership Effects on Knowledge Management}

Transformational Leadership has a positive and significant effect on Knowledge Management, which means one way to improve the process Knowledge Management in an organization and can be implemented by employees is through the leaders or organization Transformational Leadership. The things that are most influential and must be in leadership Transformational is the intellectual stimulation of the leader, so the organization can improve the application of Knowledge Management [12]. The study results that are in line with previous studies the scrutiny by Abdolreza Sadeghi, Fereshteh Mostafavi Rad [13], where the research analysis results shows that there is a relationship between leadership knowledge oriented with Knowledge Management and innovative practices and there is a significant correlation between all variables.

Managerial implications of the Transformational Leadership at BPPK are the process coffee morning that is carried out every workday morning in each unit and every Friday afternoon the activities afternoon tea is carried out at one BPPK union. In this activity structural officials will hold a discussion of what will be the target unit today and review the work carried out by employees. This activity is also a tool in Knowledge Sharing process for employees on current issues and knowledge from other employees who have finished implementing competency development. Things like this will certainly make the process Knowledge management Organizational will run successfully.

\subsubsection{Organizational Culture Effect on Knowledge Management}

There is a positive and significant influence Organizational Culture for Knowledge Management. This result is supported by previous research conducted by Bayan M. AlAbdullat, Amr Dababneh in which organizational culture has a positive and significant effect on Knowledge Management and ultimately affects job satisfaction [14]. In BPPK the managerial implementation of Organizational Culture variable is in the form of activities 
coaching and mentoring from the leader to the executor that can be carried out whenever needed. This means that with this activity the communication process, the synergy between leaders and employees will run effectively so that the application of Knowledge Management in the organization can also run smoothly.

\subsubsection{Transformational Leadership Effect on Employee Innovative Behavior}

Transformational leadership has positive and significant influence on Employee Innovative Behavior. These results are in line with the results of research studied by $\mathrm{Hui} \mathrm{Li}$, et al, where the significance of transformational leadership, trust, work involvement, and empowerment to create and improve employees' innovative work behavior. As well as research conducted by Albert Amankwaa, et.al (2019) whose results are transformational leadership behavior that positively influences the innovative behavior of employees through two mechanisms namely work autonomy and management support [18]. Managerial implications of the Transformational Leadership variable at BPPK to improve employee innovative behavior is by means of delivering ideas in solving problems at BPPK as well as evaluating employee ideas and inputting employee KPIs.

\subsubsection{Organizational Culture Effect on Employee Innovative Behavior}

There is a positive and significant influence on Organizational Culture on Employee Innovative Behavior. This result is supported by previous research conducted by Tayyaba Akram, et.al in which the collectivist social system, and the importance of organizations, work units and clans, and the importance of organizational justice in producing innovative work behavior. And in line with research conducted by LC Nawangsari, where Organizational Culture has a positive and significant influence on innovative behavior [17]. In this study it was found that the clan dimension of organizational culture is highly correlated with the dimension of issuing ideas from innovative employee behavior, meaning that organizational commitment greatly helps employees in providing creative ideas so that innovative behavior will be created in an organization. To improve employee innovative behavior, BPPK realizes the need for an organizational commitment to reward creative ideas submitted by employees. Reward given can be in the form of entry in talent management and promotion.

\subsubsection{The Influence of Knowledge Management on Employee Innovative Behavior}

Knowledge Management has a positive and significant effect on Employee Innovative Behavior. This hypothesis is supported by research conducted by Thi Phuong Linh Nguyen, et.al in which Knowledge Sharing with two main processes namely knowledge donation and knowledge gathering is related to innovative work behavior [15]. In this study it was found that the dimension of Knowledge Sharing has the highest value for increasing the issue of ideas by employees. In the BPPK the process Knowledge Sharing is common practice for leaders and employees. This process is carried out in several activities such as coffee morning, after the employee has finished training and if there is a recent update on something in the organization. This activity Knowledge Sharing is considered as one of the means in making employees issue creative ideas about a problem.

\subsubsection{The Effect of Transformational Leadership on Employee Innovative Behavior through Knowledge Management}

Transformational Leadership has positive and significant influence on Employee Innovative Behavior through Knowledge Management. The results of this study are in line 
with research Aliakbar, et.al results of the analysis show that transformational leadership has a positive, direct and meaningful effect on the process Knowledge Management and has a positive and significant effect on organizational innovation [16]. In this study it was found that the dimensions of the hypothesis testing direct and indirect the effect shows that the value of the influence of Transformational Leadership on Employee Innovative Behavior indirectly is through variables intervening Knowledge Management is higher when compared to direct.

Managerial implementation at BPPK, leaders at BPPK have implemented and developed the process Knowledge Management since 2019, from this process it makes BPPK employees more creative and innovative at work because the system has been provided, all that remains is to improve their implementation.

\subsubsection{Organizational Culture Effect on Employee Innovative Behavior through Knowledge Management}

Organizational Culture has positive and significant influence on Employee Innovative Behavior through Knowledge Management. The results of this study are in line with the results of research conducted by Tayyaba Akram, et al. The results of the analysis show that Organizational Culture has a positive, direct and meaningful effect on the Knowledge Sharing process and mediates the relationship between distributive, procedural and interactional justice and innovative work behavior of employees [13 ] In this study it was found that the dimensions of hypothesis testing direct and indirect effect seen that organizational culture influence on Innovative Behavior Employees are indirect variable that an intervening Knowledge Management is higher when compared to the direct.

This means organizations that have a culture of working to implement and support the process Knowledge Management can make employees put out their creative ideas so that the innovative behavior of employees in organizations increases. The managerial implementation at BPPK, the process of knowledge sharing that has become a culture at BPPK is expected to be able to make employees become more creative and innovative at work.

\subsubsection{Transformational Leadership Effect and Organizational Culture on Knowledge Management}

There is a positive and significant influence on Transformational Leadership and Organizational Culture on Knowledge Management. The value of the influence of these two variables if together approach the effect direct of each. In this case we can see that Transformational Leadership that has intellectual, charismatic and becomes an inspiration in an organization will create an organization that supports its employees in carrying out the. Knowledge Management process [17] Managerial implementation at BPPK, the leaders at BPPK have civilized Knowledge Management process to its employees.

\subsubsection{Transformational Leadership, Organizational Culture and Knowledge Management Effects on Employee Innovative Behavior}

Leadership Transformational, Organizational Culture has a positive and significant effect on Employee Innovative Behavior through Knowledge Management. In this study it was found that the value of the three influences on employee innovative behavior together positively, meaning that a transformational leader who applies the culture Knowledge Management as cultural values that must be applied in the organization will be able to make employee innovative behavior increase. Managerial implementation at BPPK, leaders at 
BPPK strongly support the employee competency development process, each employee is given the freedom to be able to choose what training will be followed according to discussions results with the employee's supervisor. After participating in competency development, each employee is expected to carry out a process Knowledge Sharing with other employees, so that the process of extracting creative ideas will continue in the organization.

\section{Conclusions}

Based on data exposure above, we can conclude that: (1) Transformational leadership has a positive and significant effect on Knowledge Management. While the dimension that has the lowest correlation is the dimension individual consideration of the dimension of knowledge discovery, (2) Organizational Culture has a positive and significant effect on Knowledge Management. Hierarchy dimension to the dimension Knowledge Discovery has the lowest correlation value in this study. (3) Transformational Leadership has a positive and significant effect on Employee Innovative Behavior, through the dimensions of Intellectual Stimulation has the highest correlation to the Dimensioning Ideas dimension. The dimension which has a low correlation is the dimension of Individual Consideration of the Exploration of Opportunities, (4) Organizational Culture has a positive and significant effect on Employee Innovative Behavior, in this study the results show that the Clans dimension on Organizational Culture has a very strong correlation to the Dimensioning Ideas, meaning organizations that have a high commitment to the development of human resources they have will be able to make employees issue creative ideas about organizational problems and organizational development, (5) Knowledge Management has a positive and significant effect on Employee Innovative Behavior, in this study it was found that the dimension Knowledge Sharing had a very strong correlation to the Issue dimension.

Correlation between dimensions is still low in the dimension Knowledge Discovery to the Application of Ideas, meaning that the process of capturing or capturing knowledge from experts and leaders in the organization is still not strong enough to improve the testing and marketing process of innovation carried out by organizations, (6) Transformational Leadership influences positive and significant towards Employee Innovative Behavior through Knowledge Management, (7) Organizational Culture has positive and significant influence on Employee Innovative Behavior through Knowledge Management, (8) Transformational Leadership and Organizational Culture has a positive and significant effect on Knowledge Management, in this study the influence of two Transformational Leadership variables and Organizational Culture together have greater influence than compared to the average value of the influence of these variables if directly, and (9) Transformational Leadership, Organizational Culture, Knowledge e Management has a positive and significant effect on Employee Innovative Behavior, in this study it was found that the effect value all three of the innovative behaviors of employees together are positive.

Suggestions for further research is the need for further research considering this research has limitations, the authors suggest that further research be carried out by using the interview method and deepening the variable Knowledge Sharing in improving Employee Innovative Behavior, or Employee's creative thinking influence and innovative behavior towards the competitive. 


\section{References}

[1] Yu, C., Yu, T., \& Yu, C. (2013). Knowledge Sharing, Organizational Climate, And Innovative Behavior: A Cross-Level Analysis Of Effects. Social Behavior And Personality, 41(8), 143 156.

[2] Muge Leyla Yildiz \& Ozcar, Esra Dinc (2014). Organizational Climate as a Moderator of Relationship between Transformation Leadership and Cretivity

[3] Amabile, TM, Conti, R., Coon, H., Lazenby, J., \& Herron, M. (2014). Assessing the Work Environment for Creativity Assessing The Work Environment for Creativity University of Michigan University of Southern California. Academy of Management Journal, 39(5), 11541184.

[4] Martono, S. (2013). Strategi Peningkatan Kinerja Program Studi Melalui Optimalisasi Peran Pimpinan. Jurnal Dinamika Manajemen, 4(1), 30-45.

[5] Hacker, Stephen \& Robberts, Tammy, (2004). Transformational Leadership (Creating organization of meaning). Wisconsin: Quality Press.

[6] Bass, BM (1985). Leadership and Performance Beyond Expectation. New York: Academic Press.

[7] Choi, SB, Kim, K., Ullah, SME, \& Kang, S.-W. (2016). How Transformasional Leadership Facilitates Innovative Behavior of Korean Workers Examining Mediating and Moderating Processes. Emerald Insight, 45(3), 459-479.

[8] Rio Nardo et al. (2018). Pengaruh Kepemimpinan Transformasional and Lingkungan Kerja Nonfisik Terhadap Perilaku Inovatif. Jurnal Ekonomi and Bisnis Islam Volume 3 No 2 Desember 2018.

[9] Wibisono, A. (2008). Pengaruh Iklim Organisasi terhadap Kepuasan Kerja (Studi tentang Pengaruh Iklim Organisasi terhadap Kepuasan Kerja Pegawai Puskesmas Turen di Malang). Jurnal Aplikasi Manajemen, 9(3), 1000-1010.

[10] Ghozali, Imam. (2016). Aplikasi Analisis Multivariete Dengan Program IBM SPSS 23 (Edisi 8). Cetakan ke VIII. Semarang: Badan Penerbit Universitas Diponegoro.

[11] Ramzan and Khan. ( 2010). The Impact of Organizational Comitment on Employee Job Performance. European Journal of Social Sciences 15(3) pp 292-298.

[12] Marco Alberto et al. (2016). Term Limit Extention and Electoral Participation. Evidence from a diff in Discontinuities Design at the Local Level in Italy. Diunduh dari https://www.researchgate.net/scientificcontributions/2038473219 Marco Alberto De Benedetto

[13] Abdolreza Sadeghi, Fereshteh Mostafavi Rad (2018) Transformational Leadership and Its Predictive Effect on Leadership Effectifeness. International Journal of Bussiness and Social Science 3(7) pp 186-197

[14] Bayan M. Al-Abdullat, Amr Dababneh (2018). The Mediating Effect of Job Satisfaction on Relationship Between Organizational Culture and Knowledge Management in Jordania Bussiness Sector, Brenchmarking: An International Journal, Volume 25 Issues 2 pp 517-544

[15] Li, Hui, Nazir Sajjad, Qun Wang, Asadullah Muhammad Ali, Zeb Khaqan and Shafi Amina 2019, 'Influence of Transformasional Leadership on Employees' Innovative Work Behavior in Sustainable Organizations: Test of Mediation and Moderation Processes', Sustainability 2019, 11, 1594.Thi Phuong Linh Nguyen, et.al (2019)

[16] Aliakbar, et.al (2016) Determination of Factors Affecting Student Satisfaction of Islam Azad University. Procedia Social and Behavoral Sciences 84.

[17] LC Nawangsari \& AH Sutawidjaya. (2020). Does Organizational Culture andDigital Technology Influence Behavioral Innovation in Millennial Generation1), (November 2020).

[18] Amankwaa, Albert, Michael Asiedu Gyensare, Pattanee Susomrith.'Transformasional leadership with innovative behavior Examining multiple mediating paths with PLS-SEM'. Emerald Insight, 2019.

[19] Carlucci, D., \& Schiuma, G. (2012). Evaluating Organisational Climate Through IC lens: The Case of a Public Hospital. Measuring Business Excellence, 16(479-90).

[20] Cameron, K. and R. Quinn. (2006). Diagnosing and changing organizational culture: Based on 
the competing values framework. Jossey-Bass Inc Pub. San Fransico. 